\title{
Penerapan Model Learning CyCle (LC) 7E SEbagai Upaya PeningKatan PeMahaman KonseP ASPEK MENAFSIRKAN Dan MenYimpulkan PAda MATERI Kalor Kelas X SMA
}

\author{
Lisma $^{1)}$, Yudi Kurniawan ${ }^{2)}$, Emi Sulistri ${ }^{3)}$ \\ 1) Pendidikan Fisika, STKIP Singkawang, Singkawang, Indonesia \\ E-mail:lisma4006@gmail.com \\ 2) Pendidikan Fisika, STKIP Singkawang, Singkawang, Indonesia \\ E-mail: yudikurniawan1012@gmail.com \\ 3) Pendidikan Fisika, STKIP Singkawang, Singkawang, Indonesia \\ E-mail: sulistriemi@gmail.com
}

\begin{abstract}
Abstrak. Penelitian ini bertujuan untuk mendapatkan gambaran peningkatan pemahaman konsep siswa melalui penerapan model Learning Cycle (LC) 7E pada materi kalor kelas X SMA. Jenis penelitian ini adalah penelitian kuantitatif dengan bentuk preeksperiment. Desain yang digunakan adalah one group pretest posttest design. Populasi dalam penelitian ini adalah seluruh siswa kelas X salah satu SMA Negeri di Kota Singkawang. Sampel dalam penelitian ini adalah kelas XB yang berjumlah 17 siswa dengan teknik pengambilan sampel berupa purposive sampling. Alat pengumpulan data berupa tes pemahaman konsep berbentuk pilihan ganda dan non tes yang berupa respon siswa terhadap penerapan model LC 7E. Nilai reliabilitas tes pilihan ganda sebesar 0,71 berada pada kategori tinggi. Peningkatan pemahaman konsep siswa setelah diterapkan model LC 7E pada materi kalor di kelas X mengalami peningkatan dengan $\mathrm{N}$-gain sebesar 0,78 berada pada kategori tinggi. Respon siswa terhadap penerapan model LC 7E sebesar $89 \%$ dengan kategori sangat baik.
\end{abstract}

Kata Kunci: Learning Cycle (LC) 7E, pemahaman konsep, respon, kalor

\section{PENDAHULUAN}

Ilmu Pengetahuan Alam (IPA) berkaitan dengan cara mencari tahu tentang fenomena alam secara sistematis, sehingga IPA bukan hanya penguasaan kumpulan pengetahuan yang berupa fakta-fakta, konsep-konsep atau prinsip-prinsip saja tetapi juga merupakan suatu proses penemuan [1]. Fisika merupakan satu di antara cabang IPA dengan tujuan agar siswa menguasai konsep dan prinsip fisika serta mempunyai keterampilan mengembangkan pengetahuan dan sikap percaya diri sebagai bekal untuk melanjutkan pendidikan pada jenjang yang lebih tinggi serta mengembangkan ilmu pengetahuan dan teknologi [2].

Berdasarkan tujuan dari pelajaran fisika tersebut, maka penguasaan konsep merupakan tujuan penting dalam pembelajaran fisika. Hal utama yang diperlukan agar dapat menguasai konsep adalah pemahaman terhadap konsep itu sendiri. Pemahaman adalah kemampuan seseorang dalam mengartikan, menafsirkan, menerjemahkan atau menyatakan sesuatu dengan caranya sendiri tentang pengetahuan yang pernah diterimanya [3]. Pemahaman konsep adalah kemampuan untuk mengerti dan memahami suatu konsep dan memaknai suatu materi dengan baik. Pemahaman konsep termasuk dalam satu diantara aspek hasil belajar yang diukur yakni aspek memahami, sehingga dapat disimpulkan bahwa pemahaman dapat mempengaruhi hasil belajar siswa [4].

Berdasarkan studi pendahuluan yang dilakukan di suatu SMA Kota Singkawang, rata-rata nilai ulangan siswa dalam mata pelajaran fisika masih rendah yaitu kurang dari 50, dimana masih jauh dari Kriteria Ketuntasan Minimal (KKM) yakni 70. Berdasarkan hasil wawancara dengan guru mata pelajaran fisika, rendahnya hasil ulangan siswa disebabkan siswa kurang mampu memahami pelajaran fisika dengan baik. Hal tersebut diperkuat dari hasil prariset yang dilakukan oleh peneliti untuk mengukur kemampuan pemahaman konsep siswa. Hasil prariset menunjukkan rata-rata nilai pemahaman siswa adalah 15, dengan pencapaian sebesar $15,7 \%$ pada aspek menafsirkan dan $7,1 \%$ pada aspek mencontohkan, serta $57,1 \%$ pada aspek menyimpulkan. Nilai rata-rata tersebut masih tergolong rendah dan belum mencapai KKM yang telah ditetapkan. 
Rendahnya kemampuan pemahaman konsep siswa disebabkan oleh beberapa hal, satu di antaranya adalah proses pembelajaran di dalam kelas yang masih menerapkan pembelajaran langsung, dimana dalam proses pembelajaran guru cenderung menyampaikan informasi dengan metode ceramah semata dan tidak menggunakan model pembelajaran, yakni guru menjelaskan materi kemudian memberikan contoh soal, lalu siswa mengerjakan beberapa latihan soal terkait materi yang diajarkan. Metode ceramah tidak selalu efektif dan memiliki beberapa kelemahan dalam proses pembelajaran. Kelemahan tersebut antara lain membosankan bagi siswa, mudah atau cepat lupa, sulit mengetahui apakah siswa mengerti atau tidak, kurang merangsang aktivitas, dan bersifat verbalisme [5].

Wawancara yang dilakukan dengan guru mata pelajaran fisika menyebutkan bahwa metode ceramah digunakan dengan alasan untuk mengefisienkan jumlah jam mengajar dengan materi yang akan diajarkan. Kurangnya variasi model pembelajaran yang ditemui siswa selama proses belajar seperti adanya praktikum dan diskusi kelompok yang melibatkan siswa secara keseluruhan membuat siswa merasa jenuh untuk belajar, menganggap belajar fisika itu membosankan dan sulit untuk dimengerti, sehingga berdampak pada rendahnya respon siswa terhadap pelajaran fisika. Fakta tentang respon siswa terhadap proses pembelajaran fisika di sekolah hanya $25 \%$ siswa yang merespon baik. Keadaan ini tergolong rendah dan termasuk dalam kriteria jelek [6].

Berdasarkan uraian tersebut, seharusnya dilakukan perubahan cara pembelajaran yang mampu meningkatkan pemahaman konsep siswa dengan menggunakan model pembelajaran yang berpusat kepada siswa (student centered), sehingga siswa dapat berperan lebih aktif dan meningkatkan respon siswa terhadap pembelajaran fisika. Satu diantara model yang dapat meningkatkan kemampuan pemahaman konsep siswa adalah model Learning Cycle (LC) 7E. Model pembelajaran ini dapat membantu untuk meningkatkan motivasi belajar siswa dan dapat menjadikan siswa lebih aktif karena siswa memiliki peranan yang sangat penting dalam proses belajar mengajar sehingga diharapkan siswa akan lebih mudah dalam memahami konsep fisika [7].

LC 7E memiliki tahapan yang terdiri dari Elicit, Engage, Explore, Explain, Elaborate, Evaluate, dan Extend. Fase-fase LC 7E diorganisasi sedemikian rupa sehingga siswa berperan aktif untuk dapat menguasai hal-hal yang harus dicapai dalam tujuan pembelajaran yaitu meningkatnya kemampuan pemahaman konsep siswa. Tahap Elicit dan engage pada model LC 7E dapat mengembangkan pemahaman siswa pada aspek menafsirkan dan menjelaskan, dan pada tahap explore siswa dapat mengembangkan aspek menafsirkan, menyimpulkan, membandingkan dan menjelaskan. Sedangkan pada tahap explain siswa dilatih untuk meningkatkan aspek menafsirkan, merangkum, dan menjelaskan, kemudian ditahap elaborate siswa dapat melatih mengembangkan aspek menafsirkan, menyimpulkan, membandingkan, dan menjelaskan. Tahap yang dapat mengembangkan keseluruhan aspek pemahaman konsep siswa terdapat pada dua langkah terakhir dalam LC 7E yaitu tahap evaluate dan extend [8].
Tujuan dalam penelitian ini adalah untuk mendapatkan gambaran peningkatan pemahaman konsep siswa khususnya aspek menafsirkan dan menyimpulkan melalui penerapan model LC 7E pada materi kalor kelas X di suatu SMA Kota Singkawang.

\section{METODE}

Jenis penelitian ini adalah penelitian kuantitatif, dengan bentuk pre-eksperimental. Desain yang digunakan adalah one group pretest posttest design. Populasi dalam penelitian ini adalah seluruh siswa kelas $\mathrm{X}$ satu diantara SMA Kota Singkawang tahun ajaran 2016/2017. Sampel penelitian ini terdiri dari 17 siswa kelas XB satu diantara SMA Negeri di Kota Singkawang. Teknik pengambilan sampel dalam penelitian ini berupa sampling purposive dimana sampel diambil berdasarkan pertimbangan tertentu, yang dalam hal ini adalah saran dari guru fisika yang mengajar di SMA tersebut. Teknik pengumpulan data dalam penelitian ini berupa pretest dan posttest yang diberikan sebelum dan setelah proses pembelajaran menggunakan model LC 7E.

\section{HASIL DAN PEMBAHASAN}

\section{A. Hasil Penelitian Pemahaman Konsep Siswa}

Hasil pemahaman konsep siswa diukur dengan menggunakan soal pemahaman konsep yang terdiri dari aspek menafsirkan dan menyimpulkan. Setelah mendapat data hasil pretest dan posttest, kemudian data dianalisis menggunakan uji gain yang ternormalisasi ( $N$-gain). Berdasarkan perhitungan tersebut terungkap bahwa skor rata-rata tes pemahaman konsep siswa setelah dinormalisasi diperoleh peningkatan nilai sebesar 0,78 yang berada pada kategori tinggi.

Berdasarkan aspek pemahaman konsep siswa, data peningkatan setiap aspeknya memiliki dua kategori yaitu tinggi dan sedang. Adapun hasil peningkatan aspek pemahaman konsep dapat dilihat pada Tabel 1 .

TABEL 1

Peningkatan AsPek Pemahaman KonseP

\begin{tabular}{cc}
\hline Aspek Pemahaman Konsep & Kategori \\
\hline Menafsirkan & Tinggi \\
Menyimpulkan & Sedang \\
\hline
\end{tabular}

Jumlah skor maksimal setiap aspek pemahaman konsep yang diukur sebanyak 34 poin. Pada aspek menafsirkan terjadi peningkatan skor pretest ke posttest sebanyak 25 poin, sedangkan aspek menyimpulkan terjadi peningkatan sebanyak 9 poin. Adapun grafik peningkatan skor pretest ke posttest dapat dilihat pada Gambar 1 berikut. 

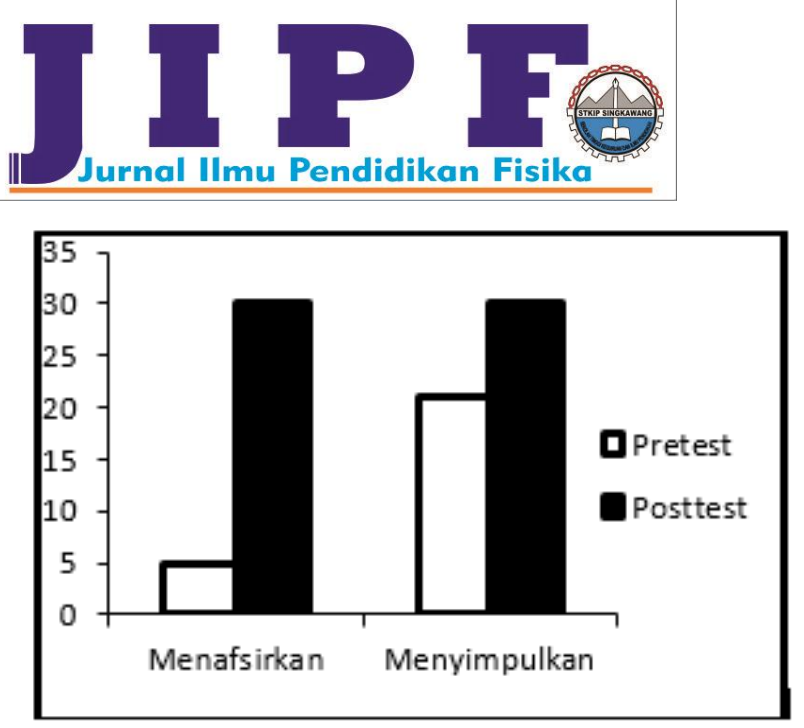

Gambar 1. Peningkatan Skor Pretest ke Posttest

Peningkatan setiap aspek dalam pemahaman konsep dianalisis menggunakan uji $N$-gain. Pada aspek menafsirkan terjadi peningkatan sebesar 0,86 dengan kategori tinggi, sedangkan aspek menyimpulkan meningkat sebesar 0,69 dengan kategori sedang. Adapun $N$-gain setiap aspek pemahaman konsep dapat dilihat pada Gambar 2 berikut.

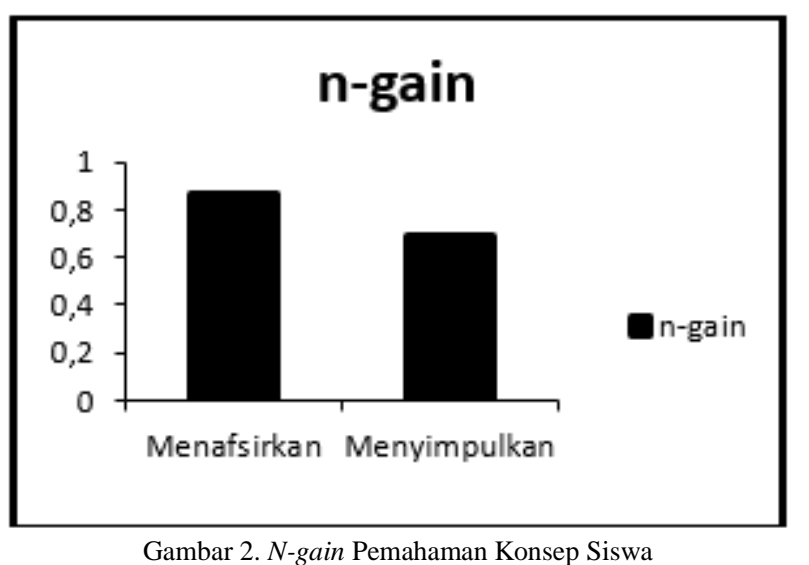

\section{B. Pembahasan Hasil Penelitian}

Berdasarkan analisis dapat dikatakan pemahaman konsep siswa setelah diterapkan model LC 7E pada materi kalor mengalami peningkatan. LC 7E dapat meningkatkan pemahaman konsep siswa karena tahap-tahap pembelajaran model ini memungkinkan siswa untuk melatih kemampuan pemahaman konsepnya. Peningkatan ini dapat terjadi karena dengan menggunakan model Learning Cycle tipe 7E siswa memiliki kesempatan untuk menyelidiki sendiri, menemukan konsep, dan menjelaskan konsep dengan bahasa yang lebih mereka pahami [7]. Peningkatan pemahaman konsep siswa diperoleh menggunakan persamaan $\mathrm{N}$-gain yaitu sebesar 0,78 yang berada pada kategori tinggi.

Pemahaman konsep siswa mengalami peningkatan di semua aspek. Peningkatan tertinggi didapat pada aspek menafsirkan dengan peningkatan sebesar 0,86 dan mempunyai kategori tinggi. Hal ini berbanding lurus dengan respon siswa yang menunjukkan bahwa $85 \%$ siswa menyatakan lebih mampu dalam aspek menafsirkan. Aspek menafsirkan mengalami peningkatan tertinggi karena pada saat berdiskusi dengan anggota kelompoknya siswa memperoleh kesempatan seluas-luasnya untuk berlatih mengubah informasi dari satu bentuk ke bentuk lain. Dengan adanya kesempatan untuk berdialog secara terbuka, siswa tidak segan untuk bertanya dan berdiskusi dalam upaya mengolah setiap informasi yang ada, lalu mengubahnya ke dalam bentuk yang lain [9].

Peningkatan pada aspek menyimpulkan berada pada kategori sedang terjadi dengan peningkatan sebesar 0,69. Penyebab peningkatan aspek menyimpulkan menjadi sedang adalah karena hasil pretest siswa telah menunjukkan angka yang tinggi sehingga saat posttest hanya terdapat sedikit peningkatan.

\section{KESIMPULAN}

Berdasarkan analisis yang dilakukan, secara umum dapat disimpulkan bahwa model LC 7E dapat meningkatkan pemahaman konsep siswa pada materi kalor di kelas X. Secara khusus dapat disimpulkan beberapa hal sebagai berikut.

1. Peningkatan pemahaman konsep siswa setelah diterapkan model LC 7E pada materi kalor di kelas X mengalami peningkatan dengan $\mathrm{N}$-gain 0,78 berada pada kategori tinggi.

2. Respon siswa terhadap penerapan model LC 7E pada materi kalor di kelas X sebesar $89 \%$ berada pada kategori sangat baik

\section{DAFTAR PUSTAKA}

[1] Permendiknas No. 22 tahun 2006. Tentang Standar Pendidikan Dasar dan Menengah. Jakarta.

[2] BNSP. 2006. Standar Isi Satuan Pendidikan Dasar dan Menengah Standar Kompetensi dan Kompetensi Dasar SMA/MA.

[3] Uno, Hamzah \& Koni, Satria. 2013. Assessment Pembelajaran. Jakarta. Bumi Aksara

[4] Rosdianto, H., Murdani, E., dan Hendra. 2017. The Implementation of POE (Predict Observe Explain) Model to Improve Student's Concept Understanding on Newton's Law. Jurnal Pendidikan Fisika Unimed, 6(1): 55-57.

[5] Daryanto. 2013. Strategi dan Tahapan Mengajar. Bandung: CV Yrama Widya.

[6] Riduwan. 2012. Skala Pengukuran Variabel-Variabel Penelitian. Bandung: Alfabeta.

[7] Nurmalasari, Resky, Kade, Amiruddin, \& Kamaluddin.2014. Pengaruh Model Learning Cycle Tipe 7e Terhadap Pemahaman Konsep Fisika Siswa Kelas VII Smp Negeri 19 Palu. Jurnal Pendidikan Fisika Tadulako. Vol. 1. No. 2: 1-6.

[8] Dewi, N.P.S.R. 2012. Pengaruh Model Siklus Belajar $7 E$ Terhadap Pemahaman Konsep dan Keterampilan Proses Siswa SMA Negeri 1 Sawan. Artikel tesis.

[9] Nuryandi, A. \& Rusdiana, D. 2016. Penerapan Dialogical Argumentation Instructional Model (Daim) Untuk Meningkatkan Pemahaman Dan Kemampuan Argumentasi Siswa Sma Pada Materi Listrik Statik. Jurnal 